Debrisoquine's greatest advantage over guanethidine is it's cost. It costs the hypertensive patient about twice as much to be treated with guanethidine as it does to be treated with debrisoquine. For most people in the developing countries, where average incomes are low, and for all people who have to pay for their own drugs this fact is important and should be borne in mind by doctors if life-long treatment of patients' hypertension is to be achieved.

We thank Dr. J. N. Adichie, head of the department of statistics,
University of Nigeria, Nsukka, for help with the statistical analysis. We are also grateful to Roche Ltd. for supplying Declinax, Ciba Ltd. for supplying Ismelin, and Pfizer Products Ltd. for supplying Renese.

\section{References}

Heffernan, A. G. A., and Carty, A. T. (1970). Irish fournal of Medical Sciences, 3, 37

Heffernan, A., et al. (1971). British Medical fournal 1, 75-8.

Prichard, B. N. C., et al. (1968). British Medical fournal, 1, 135.

\title{
Pulmonary Function in Asthmatic Patients in Remission
}

\author{
K. N. V. PALMER, G. R. KELMAN
}

British Medical fournal, 1975, 1, 485-486

\section{Summary}

Thirty-five asthmatic patients (average age 28 years) who attended a pulmonary function laboratory when their mean ratio of forced expiratory volume in one second: forced vital capacity was $81 \%$ (within the normal range for their age group) had arterial hypoxaemia and hypocapnia. These were probably secondary to lung hyperinflation and pulmonary ventilation/perfusion imbalance. The pulmonary abnormalities of bronchial asthma are not always detected by simple spirometric tests and the results of such tests should be interpreted cautiously.

\section{Introduction}

The variety and sophistication of pulmonary function tests are ever increasing, but to many doctors, particularly in general practice, "pulmonary function testing" is confined to the use of a recording spirometer, such as a Vitalograph. There are still many clinicians who, despite evidence to the contrary (Levine et al., 1970; Cade and Pain, 1973), will accept a ratio of forced expiratory volume in one second: forced vital capacity $\left(\mathrm{FEV}_{1}\right.$ : FVC) above $70 \%$ as excluding significant airways obstruction and other pulmonary dysfunction in bronchial asthma. We present here further evidence that they are wrong to do so; some patients may have significant pulmonary hyperinflation and arterial hypoxaemia with hypocapnia.

\section{Patients and Methods}

The 35 patients (13 men, 22 women) all had a clinical history of asthma with paroxysmal dyspnoea, wheezing, and blood or sputum eosinophilia or both. Their mean age $( \pm$ S.D.) was $28.3 \pm 13.8$ years. On skin-prick tests 28 reacted immediately to various allergens, mainly pollen and house-dust mite, and were considered to have extrinsic asthma. Drug treatment was discontinued for at least 12 hours before pulmonary function testing, except in one patient who was taking $5 \mathrm{mg}$ daily of prednisone by mouth and

Department of Medicine, University of Aberdeen, Aberdeen AB9 2ZD

K. N. V. PALMER, M.D., F.R.C.P., Reader in Medicine

Department of Physiology, University of Aberdeen, Aberdeen AB9 2ZD

G. R. KELMAN, M.D., M.R.C.P., Professor of Human Physiology

using an aerosol topical steroid (beclomethasone dipropionate) and one who was using the aerosol alone.

The following indicators of pulmonary function were measured: dynamic lung volumes: $\mathrm{FEV}_{1}$, FVC, the ratio $\mathrm{FEV}_{1}: \mathrm{FVC}_{\text {; static }}$ lung volumes: total lung capacity (TLC), functional residual capacity (FRC), residual volume (RV), the ratio RV:TLC; single breath carbon monoxide pulmonary diffusing capacity (DLCO); and arterial blood gases-Pao:, Paco,', and pH. The techniques used were as described previously (Palmer and Kelman, 1973).

\section{Results}

The mean values and percentage of predicted normal values are shown in table I. The mean $\mathrm{FEV}_{1}: \mathrm{FVC}$ ( \pm S.D.) was $81 \cdot 0$ $\pm 6.9 \%$, which was within the normal range for this age group (Higgins and Keller, 1973). Statistically significant differences $(\mathrm{P}<0.05)$ from the normal values predicted by Cotes (1968) were found in $\mathrm{FEV}_{1}, \mathrm{RV}$, and RV:TLC. $\mathrm{PaO}_{2}$ and $\mathrm{PaCO}_{2}$ also differed significantly $(P<0.001)$ from the normal values found by Diament and Palmer (1969) in non-asthmatic patients with an $\mathrm{FEV}_{1}: \mathrm{FVC}$ ratio greater than $70 \%$ (table II).

\section{Discussion}

Asthmatic patients in remission often continue to have abnormalities of both dynamic and static lung volumes (Levine et al., 1970; Teculescu and Stanescu, 1970; Mayfield et al., 1971; Cade and Pain, 1973). Our results show that even in patients with an $\mathrm{FEV}_{1}$ :FVC greater than $70 \%$, who therefore fall within the normal range for patients in their age group (Higgins and Keller, 1973), there is still evidence of lung hyperinflation as shown by a statistically significant increase in RV:TLC to $113 \%$ and RV to $118 \%$ of their predicted normal values. The patients we examined also had arterial hypoxaemia and hypocapnia. Their blood gas tensions were significantly less $(P<0.001)$ than predicted values (Daiment and Palmer) (table II).

The fact that these patients had moderately reduced arterial, and therefore alveolar, carbon dioxide tensions meant that their alveolar oxygen tensions were correspondingly increased so that the observed low values of arterial $\mathrm{PO}_{2}$ were indicative of a greater increase in alveolar-arterial $\mathrm{Po}_{2}$ difference than would have been the case in the absence of hypocapnia. This suggests that these patients had appreciable degrees of ventilation/ perfusion imbalance.

The degree of arterial hypoxaemia we found in asymptomatic asthmatic patients was greater than that found by others. Valabhji (1968) found no evidence of arterial hypoxaemia (mean $\mathrm{PaO}_{2} 12.7 \mathrm{kPa}(95 \mathrm{~mm} \mathrm{Hg})$ ) in 12 asymptomatic asthmatic patients with a mean $\mathrm{FEV}_{1}: \mathrm{FVC}$ of $69.7 \%$, and Cade and Pain (1973) found that the mean $\mathrm{PaO}_{2}$ was only at the lower limit of 
TABLE I-Mean Pulmonary Function Values ( \pm S.D.) in 35 Asymptomatic Patients with FEV ${ }_{1}:$ FVC Ratios greater than $70 \%$

\begin{tabular}{|c|c|c|c|c|c|c|c|c|c|c|}
\hline & $\begin{array}{c}\text { Age } \\
\text { (Years) }\end{array}$ & $\underset{(\mathrm{cm})}{\text { Height }}$ & $\underset{(\mathbf{k g})}{\text { Weight }}$ & $\underset{\text { (1) }}{\mathrm{FEV}_{1}}$ & $\underset{(1)}{\text { FVC }}$ & $\underset{(1)}{\text { TLC }}$ & $\underset{(1)}{\mathrm{FRC}}$ & $\begin{array}{c}\mathrm{RV} \\
(\mathrm{l})\end{array}$ & $\begin{array}{c}\text { RV:TLC } \\
\left(\begin{array}{c}0 \\
0\end{array}\right)\end{array}$ & $\underset{\underset{\left(\mathrm{kPa}^{-1}\right)}{\mathrm{D}_{\mathrm{L}} \mathrm{CO}}}{\underset{\mathrm{mol}^{-1}}{\min }}$ \\
\hline $\begin{array}{l}\text { Actual value } \\
\text { \% of predicted } \\
\text { normal }\end{array}$ & $28 \cdot 3 \pm 13 \cdot 8$ & $162 \cdot 5 \pm 10 \cdot 1$ & $61.9 \pm 11.3$ & $\begin{array}{r}2.9 \pm 0.8 \\
93.1 \pm 17.5\end{array}$ & $\begin{array}{r}3.5 \pm 1.0 \\
103.6 \pm 17.4\end{array}$ & $\begin{array}{r}5.1 \pm 1.2 \\
95.5 \pm 14.8\end{array}$ & $\begin{array}{r}2.8 \pm 0.8 \\
109.6 \pm 29 \cdot 3\end{array}$ & $\begin{array}{r}1.6 \pm 0.5 \\
118.2 \pm 45.0\end{array}$ & $\begin{array}{r}31 \cdot 2 \pm 7.9 \\
113.0 \pm 24 \cdot 6\end{array}$ & $\begin{array}{r}9 \cdot 2 \pm 2.5 \\
96.5 \pm 21 \cdot 6\end{array}$ \\
\hline
\end{tabular}

Conversion: SI to Traditional Units- $\mathrm{D}_{\mathrm{L}} \mathrm{co}: 1 \mathrm{mmol} \mathrm{min}^{-1} \mathrm{kPa}^{-1} \approx 3 \mathrm{ml} / \mathrm{min} / \mathrm{mm} \mathrm{Hg}$

TABLE II-Mean Arterial Blood Gas Values ( \pm S.D.) in 35 Asymptomatic Asthmatic Patients compared with Values Predicted from Regression Equations of Diament and Palmer (1969)

\begin{tabular}{l|c|c|c}
\hline & $\begin{array}{c}\mathrm{PaO}_{3} \\
(\mathrm{kPa})\end{array}$ & $\begin{array}{c}\mathrm{PaCO}_{2} \\
(\mathrm{kPa})\end{array}$ & $\mathrm{pH}$ \\
\hline $\begin{array}{c}\text { Actual value } \\
\text { Predicted value }\end{array}$ & $\begin{array}{c}11.1 \pm 1.3 \\
13.4 \pm 0.6\end{array}$ & $\begin{array}{c}4.8 \pm 0.5 \\
5.3 \pm 0.2\end{array}$ & $\mathbf{7 . 4 4} \pm 0.03$ \\
\hline
\end{tabular}

Conversion: SI to Traditional Units

Blood gases: $1 \mathrm{kPa} \approx 7.5 \mathrm{~mm} \mathrm{Hg}$

normal even when the $\mathrm{FEV}_{1}$ was reduced and there was marked lung hyperinflation (RV $156 \%$ of predicted normal). Mayfield et al. (1971) found a comparable degree of hypoxaemia, but their patients had $\mathrm{FEV}_{1}: \mathrm{FVC}$ ratios less than $70 \%$.

Thus asthmatic patients in remission may have significant degrees of arterial hypoxaemia and hypocapnia and lung hyperinflation even when their ventilatory function, as assessed by the $\mathrm{FEV}_{1}$ :FVC ratio, is normal. This is perhaps not surprising because it is becoming increasing clear that the pulmonary abnormalities of bronchial asthma-whether owing to obstruction of the small peripheral airways (less than $2 \mathrm{~mm}$ in diameter) or loss of elastic recoil in the surrounding lung parenchyma-are not always detected by the simpler spirometric tests, possibly because these tests reflect mainly changes in the calibre of the larger airways. Hence, the results of simple spirometric tests of lung function must be interpreted with care in asthmatic patients.

\section{References}

Cade, J. F., and Pain, M. C. F. (1973). Australian and New Zealand fournal of Medicine, 3, 545

Cotes, J. E. (1968). Lung function, 2nd edn., p. 384. Oxford, Blackwell. Diament, M. L., and Palmer, K. N. V. (1969). Thorax, 24, 126. Higgins, M. W., and Keller, J. B. (1973). American Review of Respiratory Disease, 108, 258

Levine, G., et al. (1970). The New England fournal of Medicine, 282, 1277. Mayfield, J. D., Paez, P. N., and Nicholson, D. P. (1971). Thorax, 26, 591. Palmer, K. N. V., and Kelman, G. R. (1973). American Review of Respirator Disease, 108, 940.

Teculescu, D., and Stanescu, D. (1970). Revue Roumaine de Medicine Interne,

Valabhji, P. (1968). Clinical Science, 34, 431.

\title{
Detection of Continuing Gluten Ingestion in Treated Coeliac Patients
}

\author{
P. G. BAKER， R. E. BARRY， A. E. READ
}

British Medical fournal, 1975, 1, 486-488

\section{Summary}

To assess the incidence and effects of continuing gluten ingestion in coeliac disease 51 adult coeliac patients were studied after four to 132 (mean 63) months on a prescribed gluten-free diet. Each patient completed a prospective dietary questionnaire, underwent a repeat jejunal biopsy, and gave serum for gluten antibody estimation.

Altogether $65 \%$ of patients were still ingesting gluten, often inadvertently. Direct questioning on dietary habits had failed to uncover most of this consumption. The gluten antibody test proved a useful screening test for detecting continuing gluten ingestion and patients with both persistent subtotal villous atrophy and gluten antibodies were almost certain to be taking large amounts $(\geqslant 2 \mathrm{~g} / \mathrm{day})$. The presence of persistent partial villous atrophy was found, however, to be an unreliable guide to gluten intake.

\footnotetext{
University Department of Medicine, Bristol Royal Infirmary, Bristol BS2 8HW

P. G. BAKER, M.B., CH.B., Research Fellow

R. E. BARRY, M.D., M.R.C.P., Registrar

A. E. READ, M.D., F.R.C.P., Professor of Medicine
}

\section{Introduction}

Since Dicke's original observation on the deleterious effect of wheat in patients with coeliac disease (Dicke, 1950) and the subsequent discovery that it was the gluten-containing fraction of wheat flour that had this effect (Dicke et al., 1953) the treatment of coeliac disease has been based on the strict exclusion of gluten from the diet. Though failure to respond clinically and morphologically to gluten withdrawal occurs in a few coeliac patients-the "steroid-dependent non-responders" (Althausen and Uyeyama, 1969)-persisting minor degrees of jejunal mucosa abnormality are commonly seen in adults who have been treated by a gluten-free diet for several years. These abnormalities are rarely seen in children with treated coeliac disease. Antibodies to gluten in the serum, stools, or duodenal juice (Berger 1958; Taylor et al., 1961; Heiner et al., 1962; Carswell and Ferguson, 1972) have been noted in some patients with coeliac disease despite several years' treatment with a gluten-free diet.

These observations could be explained on the basis of continuing gluten ingestion. This hypothesis is supported by work (Dissanayake et al., 1974) showing that many coeliac patients were not keeping to a strict gluten-free diet and that the degree of mucosal abnormality (both morphological and biochemical) was proportional to the amount of gluten being ingested. In our study we were concerned not only with determining the relationship between gluten ingestion and persisting small-bowel abnormalities but also with pinpointing the sources of gluten and the reasons for its continued ingestion. 